\title{
PENINGKATAN PENGETAHUAN CLINICAL INSTRUKTUR (CI) TENTANG PATIENT SAFETY DI RSUD KARAWANG
}

\author{
Lilis Suryani ${ }^{*}$ \\ 'Program Studi Keperawatan STIKes Horizon Karawang \\ E-mail: ${ }^{1)}$ lilis.suryanifa@gmail.com
}

\begin{abstract}
Abstrak
Pembimbing klinik atau Clinical Instructure (CI) sangat berperan dalam proses pembelajaran mahasiswa yang melaksanakan praktik di rumah sakit. Mahasiswa keperawatan yang sedang melaksanakan praktik di rumah sakit juga dapat melakukan suatu kesalahan seperti dalam pemberian obat injeksi yang berakibat kerugian pada pasien. Kesalahan tersebut dilakukan mahasiswa saat sedang tidak didampingi oleh pembimbing klinik. Dari keseluruhan masalah yang ada pada kegiatan proses bimbingan yang dilakukan oleh para pembimbing klinik pada Mitra, disepakati aspek - aspek yang menjadi prioritas untuk peningkatan kualitas pembimbing klinik Mitra yaitu; Peningkatan pemahaman peran pembimbing klinik, pasient safety, implementasi dalam proses bimbingan kepada mahasiswa yang sedang praktek di rumah sakit, serta pemahaman tentang manajemen. Tujuan dari Pengabdian Kepada Masyarakat (PKM) ini yaitu untuk meningkatkan pengetahuan serta peran pembimbing klinikyang ada di Rumah Sakit Umum Daerah (RSUD) Karawang tentang patient safety (keselamatan pasien) melalui pelatihan. Model yang diterapkan dalam pelaksanaan pelatihan ini adalah pendekatan partisipatoris yang dilakukan secara daring dikarenakan masih dalam kondisi pandemik. Melalui pelatihan ini pengetahuan pembimbing klinik rumah sakit meningkat sehingga akan memberikan dampak positif pada tindakan mahasiswa bagi keselamatan pasien.
\end{abstract}

Kata kunci: Peran Pembimbing Klinik, Patient Safety, Mahasiswa Keperawatan

\begin{abstract}
Clinical supervisors or Clinical Instructure (CI) are critical to the educational process of students who perform clinical work in hospitals. Nursing students practicing in hospitals may potentially make errors, such as incorrectly administering injectable medicines, resulting in patient losses. Students committed this error when they were not accompanied by a clinical supervisor. From all of the issues that exist in the guidance process activities performed by clinical supervisors at Partners, it has been determined that the following aspects are priorities for improving the quality of Partners clinical supervisors, such as: increased understanding of the role of clinical supervisors, patient safety, implementation in the guidance process for students practicing in hospitals, as well as management understanding. The purpose of this Community Service (PKM) is to increase clinical supervisors' knowledge and role in patient safety at the Karawang Regional General Hospital (RSUD) through training. The model used to deliver this training is a participatory approach that is conducted online due to the fact that it is still in a pandemic condition. Through this training, hospital clinical supervisors' knowledge is increased, which has a good effect on student actions regarding patient safety.
\end{abstract}

Keywords: Clinical Supervisor Role, Patient Safety, Nursing Students 


\section{PENDAHULUAN}

Rumah Sakit (RS) sebagai suatu institusi pemberi pelayanan kesehatan, melibatkan banyak tenaga keperawatan dengan jumlah kurang lebih 40-60\% dibandingkan dengan tenaga kesehatan lain, dan mempunyai kontak waktu paling lama dengan pasien serta merupakan sumber daya yang penting sebagai pemberi jasa pelayanan kesehatan di rumah sakit.

Pelayanan kesehatan yang bermutu tercermin dalam penerapan program keselamatan pasien. Adanya mahasiswa keperawatan yang sedang melaksanakan praktik di rumah sakit, tentunya turut berperan dalam menjaga mutu pelayanan yang ada di rumah sakit.

Mahasiswa yang sedang praktik di rumah sakit dapat melakukan tindakan langsung kepada pasien, dan sebagai faktor individu mahasiswa dapat juga melakukan suatu kesalahan dalam melakukan tindakan ke pasien. Fenomena yang ditemukan selama keberadaan mahasiswa di rumah sakit, ada beberapa tindakan yang mengancam keselamatan pasien, antara lain salah dalam rute pemberian obat dan salah tranfusi darah, tetapi tidak sampai terjadi ancaman kepada pasien, karena langsung diketahui dan segera dilakukan tindakan. Kondisi yang terjadi saat mahasiswa melakukan kesalahan antara lain mahasiswa tidak sedang didampingi oleh pembimbing rumah sakit, karena banyak kesibukan lain yang dirangkap dengan pekerjaan ruangan, beberapa Clinical Instructor (CI) belum memiliki sertifikat CI, dan belum memahami program bimbingan terkait pelaksanaan "patient safety". Peran pembimbing sangat diperlukan dalam proses pembelajaran mahasiswa dan menjaga mutu perawatan dan keselamatan kepada pasien (Dahlke et al., 2012; Kim et al., 2013; Lewallen \& DeBrew, 2012).

Kelalaian individu merupakan ancaman terjadinya kejadian yang tidak diharapkan pada pasien. Institut Medicine of America melaporkan 100.000 orang meninggal setiap tahun sebagai akibat dari kesalahan medis, kesalahan berasal dari efek samping obat, komplikasi bedah, kesalahan sistem, dan kesalahan pengobatan. Studi di Kanada didapatkan 7-12\% pasien di rumah sakit mengalami efek samping obat dan 30-40\% dari peristiwa itu dapat dicegah (Montoya \& Kimball, 2013). Berdasarkan laporan tersebut maka penting untuk meningkatkan program keselamatan pasien.

Keselamatan pasien merupakan hal yang sangat mendasar dan merupakan hak bagi setiap pasien. Oleh karena itu keselamatan pasien harus mendapatkan prioritas untuk diperhatikan dan dilaksanakan. Terkait keberadaan mahasiswa yang sedang melaksanakan praktik dan kaitannya dengan keamanan dan keselamatan pasien, maka sangat diperlukan peran pembimbing klinik/CI dalam rangka menjaga keamanan dan keselamatan pasien serta pencapaian kompetensi pembelajaran (Depkes, 2008; Menkes, 2011). Berdasarkan hasil penelitian Suryani (2014) peran pembimbing klinik RS/ CI berpengaruh terhadap pelaksanaan "patient safety" oleh mahasiswa. Mahasiswa perlu melaksanakan dan menerapkan program keselamatan pasien sehingga dapat mencegah adanya cedera pada pasien.

\section{METODE PENELITIAN}

Kegiatan ini dilaksanakan dua hari pada tanggal 4 - 5 Oktober 2020 dilakukan secara daring sebanyak 20 peserta pembimbing klinik RSUD Karawang. Hari pertama dilakukan pre-test terkait peran pembimbing klinik yang berhubungan dengan keselamatan pasien dan 
pemberian materi. Hari kedua dilakukan simulasi tugas pembimbing klinik secara berkelompok melalui case study dan di akhiri dengan pemberian post-test.

\section{HASIL DAN PEMBAHASAN}

\subsection{Hari Pertama Pemberian Materi dan Pre-test}

Pemahaman tentang pelaksanaan patient safety merupakan hal yang mendasar dalam menerapkan bagaimana implementasi dalam membimbing mahasiswa tentang patient safety (Parsh, 2010). Oleh karenanya di hari pertama dilaksanakan pre-test sebelum pemberian materi dengan maksud untuk mengukur sejauh mana pemahaman pembimbing klinik di rumah sakit terkait peran pembimbing klinik, pasien safety, implementasi dalam proses bimbingan kepada mahasiswa yang sedang praktek di rumah sakit, serta pemahaman tentang manajemen. Berikutnya adalah pemberian materi- materi yang disebutkan di atas.

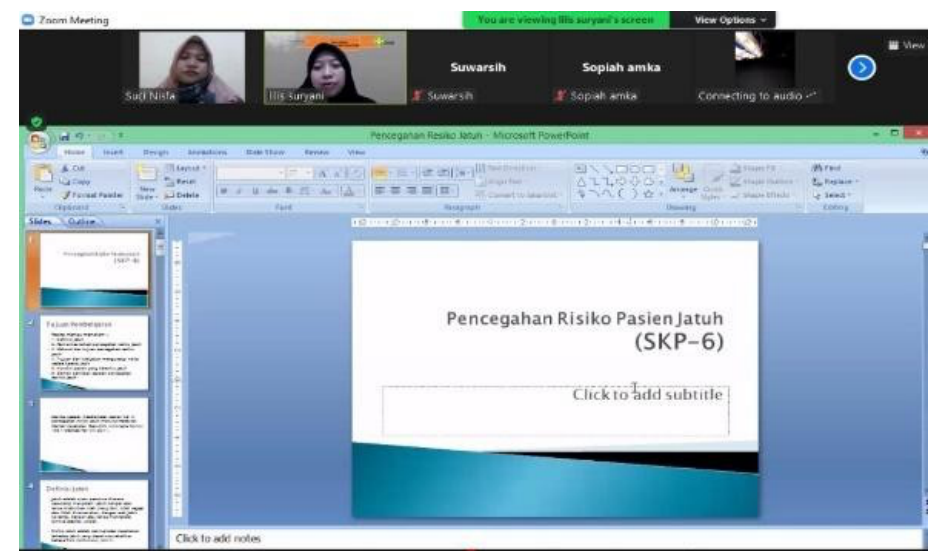

Gambar 1 Salah satu materi yang diberikan dalam pelatihan

\subsection{Hari Kedua Simulasi Case Study dan Post Test}

Di hari kedua peserta sebanyak 20 orang dibagi kedalam 3 (tiga) kelompok yang masing-masing diberikan case study dan harus disimulasikan atau dilakukan pemecahan masalahnya sesuai dengan perannya masing-masing sebagai pembimbing klinik di rumah sakit dengan memperhatikan hal-hal yang berkaitan dengan pasien safety. Peserta sangat antusias dan terlihat aktif dan berusaha memahami dalam melakukan peran pembimbing klinik. Jika pembimbing tidak memahami maka sulit untuk mencapai target kompetensi yang diharapkan oleh mahasiswa terkait pasient safety, dan akhirnya hal kemungkinan terjadi halyang tidak diharapkan bagi pasien (Marquis \& Huton, 2006). 


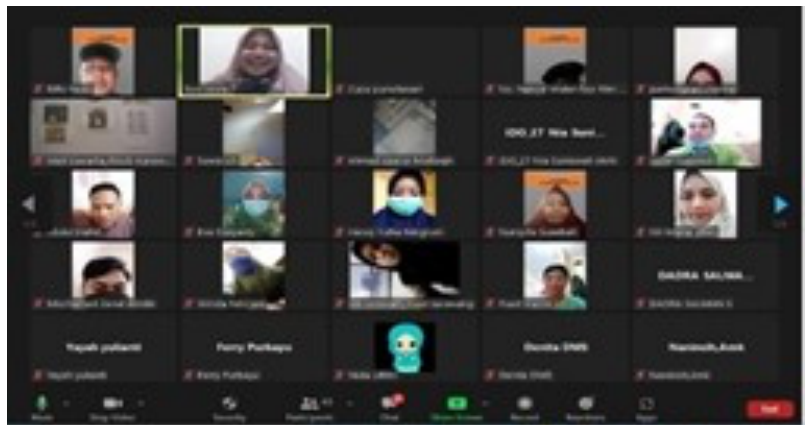

Gambar 2. Peserta Melakukan Case Study berkelompok

Selain pemahaman terkait pasien safety juga tidak kalah pentingnya yaitu bagaimana pembimbing klinik mengatur waktu dalam proses bimbingan, misalnya seorang pembimbing klinik tidak dibebani dengan banyak tugas manajerial ruangan atau pun beban lebih dalam memberikan asuhan kepada pasien, dengan demikian bimbingan kepada mahasiswa menjadi tidak optimal, dan keamanan bagi pasien akan terancam. Dari hasil post-test diperoleh adanya peningkatan pengetahuan tentang pasien safety dan peran pembimbing klinik.

\section{KESIMPULAN}

Pelatihan pasien safety bagi pembimbing klinik sangat bermanfaat dan bisa menjawab permasalahan yang terjadi di lapangan. Pihak RSUD Karawang sebagai mitra sangat menyambut positif atas kegiatan yang telah dilaksanakan melalaui kegiatan pelatihan dan pendampingan serta evaluasi, sehingga para pembimbing klinik dapat lebih optimal dalam menjalankan perannya saat membimbing mahasiswa yang sedang praktek, sehingga dapat terhindar dari hal-hal yang dapat menimbulkan ancaman bagi pasien selama mahasiswa praktek jika tidak dibimbing dengan optimal.

\section{DAFTAR PUSTAKA}

Dahlke, S., Baumbusch, J., Affleck, F., \& Kwon, J.-Y. (2012). The clinical instructor role in nursing education: A structured literature review. Journal of Nursing Education, 51(12), 692-696.

Depkes, R. I. (2008). Panduan nasional keselamatan pasien rumah sakit (patient safety). Depkes RI Jakarta.

Kim, C.-J., Park, J.-W., \& Kang, S.-W. (2013). Effects of a collaborative clinical practicum on clinical practice ability and teaching effectiveness among nursing students. Journal of Nursing Education and Practice, 3(12), 143.

Lewallen, L. P., \& DeBrew, J. K. (2012). Successful and unsuccessful clinical nursing students. Journal of Nursing Education, 51(7), 389-395.

Marquis, B. L., \& Huton, C. J. (2006). Leadership roles and management functions in nursing: theory and application 5th edition. Manila, Philippines: Lippincott Williams \& Wilkins.

Menkes, R. I. (2011). Peraturan Menteri Kesehatan Republik Indonesia Nomor 1691/Menkes/Per/VIII/2011. Tentang Keselamatan Pasien Rumah Sakit. Jakarta:. Kemenkes, RI. 
Montoya, I. D., \& Kimball, O. M. (2013). Gauging patient safety programs. Journal of Allied Health, 42(3), 182-186.

Parsh, B. (2010). Characteristics of effective simulated clinical experience instructors: Interviews with undergraduate nursing students. Journal of Nursing Education, 49(10), $569-572$.

Suryani, L. (2014). Hubungan peran pembimbing klinik RSUD Karawang dengan pelaksanaan keselamatan pasien oleh mahasiswa STIKES Kharisma Karawang. Suryani, L. (2014). Hubungan Peran Pembimbing Klinik RSUD Karawang Dengan Pelaksanaan Keselamatan Pasien Oleh Mahasiswa STIKES Kharisma Karawang Doi:Http://Lib.Ui.Ac.Id/Detail.Jsp?Id=20389930\&.

http://lib.ui.ac.id/detail.jsp?id=20389930\&lokasi=lokal 
